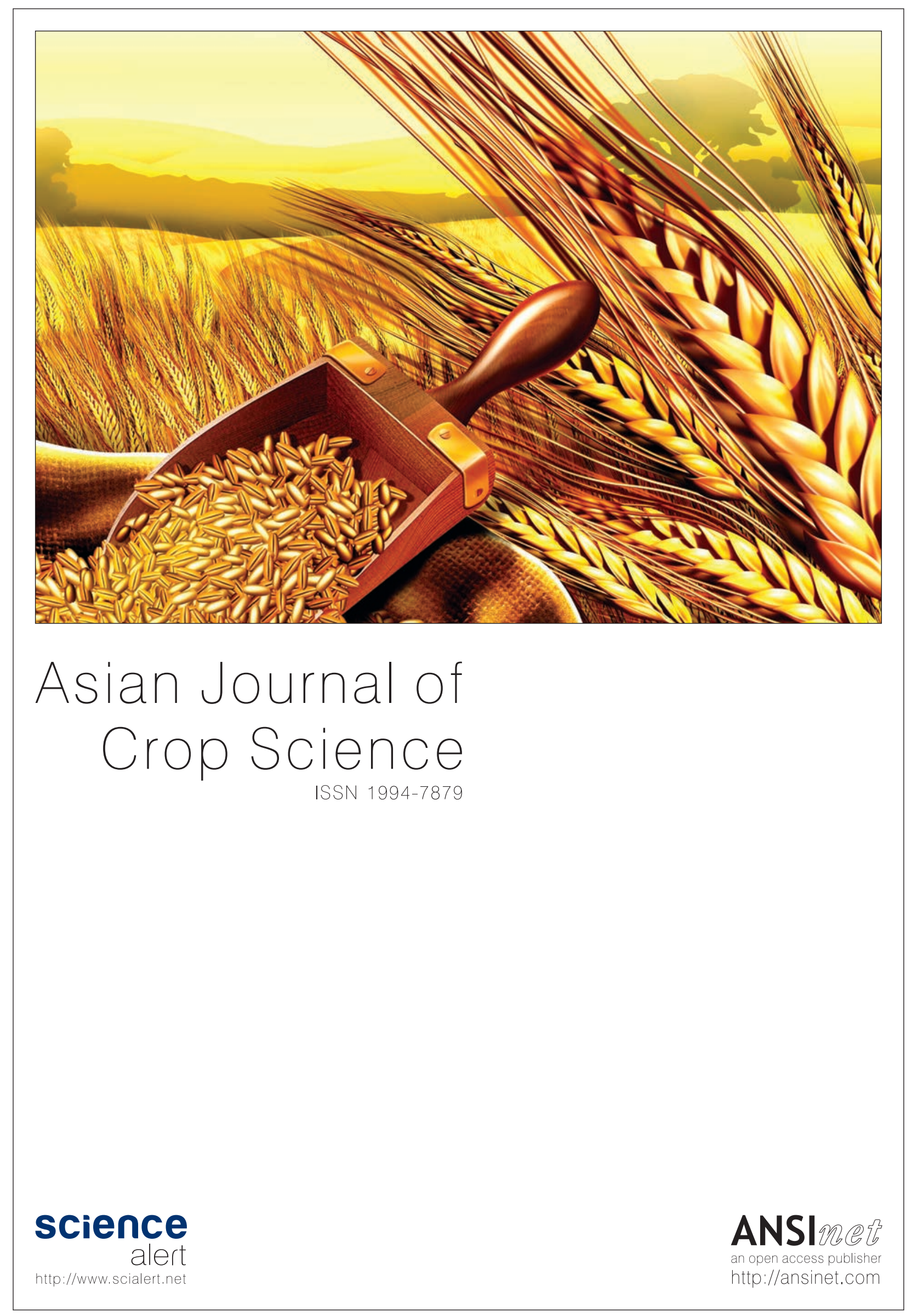




\title{
Biomass, Carbon Stock and Oxygen Produced by Mangrove Vegetation in Tropical Forest in Central Kalimantan, Indonesia
}

\author{
Ajun Junaedi, Nisfiatul Hidayat, Yuanita Mediawati, Agung Wibowo, Moh Rizal, Setiarno and \\ I Nyoman Surasana
}

Department of Forestry, Faculty of Agriculture, University of Palangka Raya, Kampus UPR Tunjung Nyaho, Jalan Yos Sudarso, Kotak Pos 2/PLKUP, 73111, Palangka Raya, Central Kalimantan, Indonesia

\section{Abstract}

Background and Objective: The mangrove conversion in Indonesia is running massively, although its ecological function in climate change mitigation cannot be replaced by physical buildings made by humans. This study was aim at analyzing the composition of species, biomass, carbon stock and oxygen produced by mangrove vegetation. Materials and Methods: The study site was in mangrove forest at Kubu village, West Kotawaringin district, Central Kalimantan province, Indonesia. Estimation of biomass, carbon stock and oxygen produced by mangrove were calculated using combination of destructive and non-destructive methods. Results: The results show that the number of mangrove species found as many as 13 species, from 7 families and mostly included in the major mangrove species group. The species that dominating at all growth phases is Rhizophora stylosa, indicated by its highest importance value index (IVI). The total potential of biomass, carbon stock and oxygen produced are $97.12,45.65 \mathrm{t} \mathrm{ha}^{-1}$ and $121.88 \mathrm{O}_{2} \mathrm{t} \mathrm{ha}^{-1}$, respectively. The most dominant type of vegetation is Rhizophora stylosa in the growth phase of trees, saplings and seedlings. Conclusion: The authors call for mangrove forest conservation activities in order to increase the potential of biomass storage, carbon stocks and oxygen production.

Key words: Biomass, carbon, oxygen, Rhizophora stylosa, mangrove

Citation: Ajun Junaedi, Nisfiatul Hidayat, Yuanita Mediawati, Agung Wibowo, Moh Rizal, Setiarno and I Nyoman Surasana, 2020. Biomass, carbon stock and oxygen produced by mangrove vegetation in tropical forest in central Kalimantan, Indonesia. Asian J. Crop Sci., 12: 26-33.

Corresponding Author: Ajun Junaedi, Department of Forestry, Faculty of Agriculture, University of Palangka Raya, Kampus UPR Tunjung Nyaho, Jalan Yos Sudarso, Kotak Pos 2/PLKUP, 73111, Palangka Raya, Central Kalimantan, Indonesia

Copyright: () 2020 Ajun Junaedi etal. This is an open access article distributed under the terms of the creative commons attribution License, which permits unrestricted use, distribution and reproduction in any medium, provided the original author and source are credited.

Competing Interest: The authors have declared that no competing interest exists.

Data Availability: All relevant data are within the paper and its supporting information files. 


\section{INTRODUCTION}

The mangrove forest ecosystem in Indonesia is currently facing the threat of conversion into ponds, hotels, tourism and human settlements ${ }^{1}$. This pressure occurs because the community prohibited from utilising forest for non-forest-related purposes ${ }^{2}$. As a result, people choose the coastal zone, where the mangrove ecosystem is placed, for daily economic activities, because occupying the area will lead to lower legal consequences. Mangrove ecosystems have long been a source of livelihood for local people who live below the poverty line $\mathrm{e}^{3}$. Thus, mangrove conversion not only threatens the survival of coastal ecosystems but also suppresses the livelihoods of local communities ${ }^{4}$.

On the other hand, various studies have shown the importance of mangrove forests as habitat for fish, shrimp, crabs, wood energy producer ${ }^{5}$, as well as to protect those who live around the coast from the dangers of Tsunami and tidal waves ${ }^{6}$. The Indonesian government has spent much money to build physical buildings in order to prevent coastal abrasion, protect the coast from waves and seawater intrusion. Even mangrove ecosystems can cover all environmental services that are provided by those physical buildings.

People assume mangrove vegetation species and their ability to support coastal ecosystem life are indifferent. This fact causes the parties to view mangrove forests as something homogeneous. In fact, the ability of mangrove vegetation to store biomass and carbon and its ability to produce oxygen varies. Oxygen is essential in improving the quality of living things around the coast ${ }^{7}$. Furthermore, the ecological function of mangroves in mitigating climate change cannot be replaced by physical buildings made by humans. Before these reasons, this study aim to analyze the composition of mangrove species along with biomass and carbon stock and their ability to produce oxygen.

\section{MATERIALS AND METHODS}

Study area: Research site is mangrove forest located in Kubu Village, Kumai District, Kotawaringin Barat Regency, Central Kalimantan Province. The data were collected for 3 months, from June to August 2018. The research area is lowland with altitudes of 1-5 m from sea level. Its climatic conditions categorized into Type A according to Schmidt and Ferguson with dry season from June to September and the highest rainy season in December. The maximum air temperature ranges between $30.7-32.6^{\circ} \mathrm{C}$ and the minimum air temperature ${ }^{8}$ around $22.7-23.5^{\circ} \mathrm{C}$.
Research procedures: Data collection is distinguished based on the vegetation growth phase, namely trees, saplings and seedlings. The tree is vegetation with a trunk diameter of $\geq 10 \mathrm{~cm}$, when saplings with a diameter of $<10 \mathrm{~cm}$ and a height of $>1.5 \mathrm{~m}$ and seedlings with height $<1.5 \mathrm{~m}^{9}$. The sample plot was a combination of lines and checkered lines. The number of the lane was 2 , with the length and width of each was 400 and $10 \mathrm{~m}$, respectively and distance between the two lanes was $150 \mathrm{~m}$. Observation plots are set in each lane with a size of $10 \times 10 \mathrm{~m}$ for tree phase, $5 \times 5 \mathrm{~m}$ for sapling phase and $2 \times 2 \mathrm{~m}$ for seedling phase. Vegetation data collected include vegetation species, diameter, total height and number of individuals.

\section{Data analysis}

Analysis of vegetation: The parameters of mangrove composition species calculated included: Number of species, individual density and important value index (IVI) at each growth phase. The IVI for tree growth phase was the sum of relative density, relative frequency and relative dominance ${ }^{10,11}$, whereas IVI for sapling and seedling phases was the sum of relative density and relative frequency.

Biomass stock: Above and below-ground biomass stock for tree and sapling phases were calculated using allometric equations for each mangrove species found with the diameter and wood density as independent variables. Allometric equations is a formula widely used by scientists to estimate biomass and calculate biomass carbon stored in certain species of tree or forest area12. Types of allometric equations for estimating above and below-ground biomass deposits as in Table 1 and 2.

This biomass estimation equation was also used by Kauffman ${ }^{23}$ while calculated mangrove biomass for tree and sapling phases.

The amount of above and below ground biomass for seedlings was analyzed using destructive methods ${ }^{24}$. In the destructive method, the seedling vegetation in the $2 \times 2 \mathrm{~m}$ sample plot is removed. The seedlings are then separated into stems, leaves, roots and each is weighed to obtain its wet weight $\left(\mathrm{BB}_{\text {total }}\right)$. A total of $100-300 \mathrm{~g}$ of stems, leaves and roots were taken for sub-samples $\left(\mathrm{BB}_{\text {sub sample }}\right)$ and was dried in an oven at $80^{\circ} \mathrm{C}$ for $48 \mathrm{~h}$ and weighed to obtain its dry weight $\left(B K_{\text {sub sample }}\right)$. Seedling biomass is the ratio of the dry weight of sub-sample $\mathrm{BK}_{\text {sub sample }}$ to the $\mathrm{BB}_{\text {sub sample }}$ multiplied by $\mathrm{BB}_{\text {total }}$. The total stored biomass of mangrove vegetation is the sum of biomass in the growth phase of trees, saplings and seedlings. 
Asian J. Crop Sci., 12 (1): 26-33, 2020

Table 1: Allometric equations used to estimate aboveground biomass stock at tree and sapling growth phases

\begin{tabular}{|c|c|c|c|}
\hline Mangrove species & Allometric equations & References & Wood specific gravity $(\rho) I_{T T}^{19}\left(\mathrm{~g} \mathrm{~cm}^{-3}\right)$ \\
\hline Rhizophora stylosa & $W=0.251 \times \rho \times D^{2.46}$ & Komiyama et a/.13 & 0.913 \\
\hline Rhizophora mucronata & $W=0.1466 \times D^{2.3136}$ & Dharmawan ${ }^{14}$ & - \\
\hline Avicennia marina & $W=0.2905 \times D^{2.2598}$ & Dharmawan and Siregar ${ }^{15}$ & - \\
\hline Xylocarpus granatum & $W=0.0823 \times D^{2.59}$ & Clough and Scott ${ }^{16}$ & - \\
\hline Xylocarpus moluccensis & $W=0.1823 \times D^{2.21}$ & Tarlan $^{17}$ & - \\
\hline Bruguiera cylindrical & $W=0.251 \times \rho \times D^{2.46}$ & Komiyama et al.13 & 0.763 \\
\hline Sonneratia alba & $W=0.1848 \times \rho \times D^{2.3524}$ & Dharmawan and Siregar ${ }^{15}$ & 0.647 \\
\hline Lumnitzera littorea & $W=0.251 \times \rho \times D^{2.46}$ & Komiyama et $a l^{13}$ & 0.737 \\
\hline Bruguiera parviflora & $W=0.168 \times D^{2.42}$ & Clough and Scott ${ }^{16}$ & - \\
\hline Bruguiera gymnorrhiza & $W=0.0754 \times \rho \times D^{2.505}$ & Kauffman and Donato ${ }^{18}$ & 0.730 \\
\hline Sonneratia spp. & $W=0.1848 \times \rho \times D^{2.3524}$ & Dharmawan and Siregar ${ }^{15}$ & 0.340 \\
\hline Cerbera manghas & $W=0.251 \times \rho \times D^{2.46}$ & Komiyama et $a / .{ }^{13}$ & 0.380 \\
\hline Hibiscus tilliaceus & $W=0.251 \times \rho \times D^{2.46}$ & Komiyama et al.13 & 0.550 \\
\hline
\end{tabular}

W: Aboveground biomass $\left(\mathrm{kg}\right.$ tree $\left.{ }^{-1}\right)$, D: Tree diameter at $1.3 \mathrm{~m}$ above ground level or $20 \mathrm{~cm}$ above root support and buttresses $(\mathrm{cm})$

Table 2: Allometric equations used to estimate belowground biomass stock at tree and sapling growth phases

\begin{tabular}{|c|c|c|c|}
\hline Mangrove Species & Allometric equations & References & Wood specific gravity $(\rho) I T O^{19}\left(\mathrm{~g} \mathrm{~cm}^{-3}\right)$ \\
\hline Rhizophora stylosa & $W R=0.261 D^{1.86}$ & Comley and McGuinness 20 & - \\
\hline \multirow[t]{2}{*}{ Rhizophora mucronata } & $W R=0.00974\left(D^{2} H\right)^{1.05}$ & & \\
\hline & $H=D /(0.02 D+0.678)$ & Tamai et al. ${ }^{21}$ & - \\
\hline Avicennia marina & $W R=1.28 D^{1.17}$ & Comley and McGuinness ${ }^{20}$ & - \\
\hline Xylocarpus granatum & $W R=0.145 D^{2.25}$ & Poungparn et al.22 & - \\
\hline Xylocarpus moluccensis & $W R=0.199 \rho^{0.899} D^{2.22}$ & Poungparn et al. ${ }^{13}$ & 0.571 \\
\hline \multirow[t]{2}{*}{ Bruguiera cylindrical } & $W R=0.0188\left(D^{2} H\right)^{0.909}$ & & \\
\hline & $\mathrm{H}=\mathrm{D} /(0.025 \mathrm{D}+0.583)$ & Tamai et al. ${ }^{21}$ & - \\
\hline Sonneratia alba & $W R=0.199 \rho^{0.899} D^{2.22}$ & Poungparn et al.13 & 0.647 \\
\hline Lumnitzera littorea & $W R=0.199 \rho^{0.899} D^{2.22}$ & Poungparn et al. ${ }^{13}$ & 0.737 \\
\hline \multirow[t]{2}{*}{ Bruguiera parviflora } & $W R=0.0188\left(D^{2} H\right)^{0.909}$ & & \\
\hline & $H=D /(0.025 D+0.583)$ & Tamai et al. ${ }^{21}$ & - \\
\hline \multirow[t]{2}{*}{ Bruguiera gymnorrhiza } & $W R=0.0188\left(D^{2} H\right)^{0.909}$ & & \\
\hline & $\mathrm{H}=\mathrm{D} /(0.025 \mathrm{D}+0.583)$ & Tamai et al. ${ }^{21}$ & - \\
\hline Sonneratiaspp. & $W R=0.199 \rho^{0.899} D^{2.22}$ & Poungparn et $a l^{13}$ & 0.340 \\
\hline Cerbera manghas & $W R=0.199 \rho^{0.899} D^{2.22}$ & Poungparn et al.13 & 0.380 \\
\hline Hibiscus tilliaceus & $W R=0.199 \rho^{0,899} D^{2.22}$ & Poungparn et al. ${ }^{13}$ & 0.550 \\
\hline
\end{tabular}

WR: Belowground biomass $\left(\mathrm{kg}\right.$ tree $\left.{ }^{-1}\right)$, D: Tress diameter at $1.3 \mathrm{~m}$ aboveground level or $20 \mathrm{~cm}$ above root support and buttresses $(\mathrm{cm})$

Carbon stock: Carbon stored in each mangrove species is estimated using the formula taken from Badan Standar Nasional Indonesia or Indonesian National Standardization Agency $^{25}$, namely:

$$
\mathrm{C}_{\mathrm{T}}=\mathrm{W}_{\mathrm{T}} \times 0.47
$$

Where:

$\mathrm{C}_{\mathrm{T}}=$ Total vegetation carbon stock $\left(\mathrm{t} \mathrm{ha}^{-1} \mathrm{C}\right)$

$\mathrm{W}_{\mathrm{T}}=$ Total vegetation biomass $\left(\mathrm{t} \mathrm{ha}^{-1}\right)$

$0.47=$ Organic-C fraction

Oxygen production: The amount of oxygen produced by mangrove vegetation is the result of multiplication between the amount of carbon stored with the weight ratio of oxygen atoms with carbon ${ }^{26}$, which is formulated as follows:

$$
\mathrm{O}_{2}=\mathrm{C}_{\mathrm{T}} \times 2.67
$$

Where:

$\mathrm{O}_{2}=$ Oxygen produced by vegetation $\left(\mathrm{O}_{2} \mathrm{tha}^{-1}\right)$

$\mathrm{C}_{\mathrm{T}}=$ Total vegetation carbon stock $\left(\mathrm{t} \mathrm{ha}^{-1} \mathrm{C}\right)$

$2.67=$ Ratio of atomic weights of $\mathrm{O}_{2}$ to $\mathrm{C}(32 / 12)$

\section{RESULTS}

Species composition: There are 13 species of mangroves found at the study site. They originate from 7 families, namely Rhizophoraceae (5 species), Meliaceae (2 species), Sonneratiaceae (2 species), Avicenniaceae (1 species), Combretaceae (1 species), Apocynaceae (1 species) and Malvaceae (1 species). It is widely known that, floristically, mangrove vegetation can be classified into 3 groups, namely major mangrove, minor mangrove and association mangrove. Table 3 presents mangrove species found at the study site based on its floristic classification. 
Asian J. Crop Sci., 12 (1): 26-33, 2020

Table 3: Classification of mangrove vegetation types found at research locations

\begin{tabular}{llcc}
\hline & & Mangrove type classification & Association Mangrove \\
Vegetation species & Family & Major Mangrove & Minor Mangrove \\
\hline Rhizophora stylosa & Rhizophoraceae & $\checkmark$ & $\checkmark$ \\
Rhizophora mucronata & Rhizophoraceae & $\checkmark$ & $\checkmark$ \\
Avicennia marina & Avicenniaceae & Meliaceae & \\
Xylocarpus granatum & Meliaceae & $\checkmark$ & $\checkmark$ \\
Xylocarpus moluccensis & Rhizophoraceae & $\checkmark$ & $\checkmark$ \\
Bruguiera cylindrical & Rhizophoraceae & $\checkmark$ & \\
Bruguiera gymnorrhiza & Rhizophoraceae & $\checkmark$ & \\
Bruguiera parviflora & Combretaceae & $\checkmark$ & \\
Lumnitzera littorea & Sonneratiaceae & & \\
Sonneratia alba & Sonneratiaceae & & \\
Sonneratia caseolaris & Apocynaceae & & \\
Cerbera manghas & Malvaceae & & \\
Hibiscus tilliaceus & & & \\
Total & & & \\
\hline
\end{tabular}

Table 4: Mangrove vegetation density in the growth phase of tree, sapling and seedling

\begin{tabular}{lcc}
\hline Growth phases & Individual density $\left(\mathrm{N} \mathrm{ha}^{-1}\right)$ & Percentage \\
\hline Tree & 264 & 4.73 \\
Sapling & 1125 & 20.17 \\
Seedling & 4188 & 75.10 \\
Total & 5577 & 100.00 \\
\hline
\end{tabular}

Table 5: Importance value index (IVI) of five most dominant mangrove species in growth phase of tree, sapling and seedling

\begin{tabular}{lcll}
\hline Growth phases & Rank & Vegetation species & IVI (\%) \\
\hline Tree & 1 & Rhizophora stylosa & 60.32 \\
& 2 & Xylocarpus granatum & 42.49 \\
& 3 & Avicennia marina & 39.47 \\
Sapling & 4 & Xylocarpus moluccensis & 29.04 \\
& 5 & Sonneratia alba & 27.59 \\
& 1 & Rhizophora stylosa & 40.41 \\
& 2 & Avicennia marina & 26.26 \\
Seedling & 3 & Xylocarpus granatum & 24.69 \\
& 4 & Xylocarpus moluccensis & 17.05 \\
& 5 & Bruguiera parviflora & 16.61 \\
& 1 & Rhizophora stylosa & 70.44 \\
& 2 & Avicennia marina & 40.95 \\
& 3 & Sonneratia alba & 36.48 \\
& 4 & Lumnitzera littorea & 19.93 \\
& 5 & Xylocarpus moluccensis & 10.58 \\
\hline
\end{tabular}

Table 3 shows that there are 9 major mangrove species, 2 minor mangroves and 2 association mangroves. Mangrove vegetation density based on the growth phase ranges from 264-4188 $\mathrm{N} \mathrm{ha}^{-1}$ with a total density of $5577 \mathrm{~N} \mathrm{ha}^{-1}$. The seedling growth phase has the highest density $(75.10 \%)$ compared to saplings (20.17\%) and trees (4.73\%). Mangrove vegetation density based on the growth phase is shown in Table 4.

The mangrove species dominating in all growth phase is Rhizophora stylosa, which is indicated by its highest importance value index (IVI). The Importance value index is one of the parameters used in determining species
Table 6: Biomass stock above and belowground at tree and sapling growth phases

\begin{tabular}{|c|c|c|c|c|c|c|}
\hline \multirow[b]{3}{*}{ Vegetation species } & \multicolumn{6}{|c|}{ Biomass stock in the growth phase } \\
\hline & \multicolumn{3}{|c|}{ Tree $\left(\mathrm{t} \mathrm{ha}^{-1}\right)$} & \multicolumn{3}{|c|}{ Sapling ( $\mathrm{tha}^{-1}$ ) } \\
\hline & AGB & BGB & Total & AGB & $B G B$ & Total \\
\hline Avicennia marina & 7.57 & 1.32 & 8.89 & 1.86 & 1.27 & 3.13 \\
\hline Bruguiera cylindrical & 6.05 & 1.23 & 7.28 & 0.45 & 0.08 & 0.54 \\
\hline Bruguiera gymnorrhiza & 0.72 & 0.45 & 1.17 & 0.27 & 0.16 & 0.43 \\
\hline Bruguiera parviflora & 3.25 & 0.83 & 4.08 & 1.25 & 0.30 & 1.55 \\
\hline Cerbera manghas & 0.91 & 0.40 & 1.31 & 0.11 & 0.06 & 0.17 \\
\hline Hibiscus tilliaceus & 1.47 & 0.61 & 2.08 & 0.40 & 0.22 & 0.62 \\
\hline Lumnitzer alittorea & 3.89 & 1.55 & 5.44 & 0.91 & 0.47 & 1.38 \\
\hline Rhizophora mucronata & 0.36 & 0.22 & 0.58 & 0.05 & 0.02 & 0.07 \\
\hline Rhizophora stylosa & 11.27 & 2.50 & 13.77 & 4.85 & 1.73 & 6.58 \\
\hline Sonneratia alba & 5.73 & 4.09 & 9.82 & 0.57 & 0.50 & 1.07 \\
\hline Sonneratia caseolaris & 1.50 & 1.16 & 2.66 & 1.32 & 0.17 & 1.48 \\
\hline Xylocarpus granatum & 9.24 & 5.49 & 14.73 & 1.41 & 1.29 & 2.71 \\
\hline Xylocarpus moluccensis & 2.70 & 1.83 & 4.53 & 0.58 & 0.39 & 0.97 \\
\hline Total & 54.66 & 21.68 & 76.34 & 14.03 & 6.67 & 20.70 \\
\hline \multicolumn{7}{|c|}{ AGB: Aboveground biomass, BGB: Belowground biomass } \\
\hline \multicolumn{7}{|c|}{ able 7: Biomass stock above and belowground } \\
\hline Growth phase & $A G B$ & & $B C$ & & & Total \\
\hline Seedling & 0.06 & & 0. & & & 0.08 \\
\hline
\end{tabular}

dominance in a forest association. The IVI data of 5 most dominant mangrove species according to their growth phase are served in Table 5.

Biomass stock: Biomass stock (above and below ground) in the growth phase of trees, saplings and seedlings are $76.34,20.70$ and $0.08 \mathrm{t} \mathrm{ha}^{-1}$, respectively, so that the total biomass storage of mangrove vegetation is $97.12 \mathrm{t} \mathrm{ha}^{-1}$. Data on above and belowground vegetation biomass storage at the tree, sapling and seedling growth stages is shown in Table 6 and 7. 
Asian J. Crop Sci., 12 (1): 26-33, 2020

Table 8: Carbon storage and oxygen produced by mangrove vegetation in tree and sapling growth stages

\begin{tabular}{|c|c|c|c|c|}
\hline \multirow[b]{2}{*}{ Vegetation species } & \multicolumn{2}{|c|}{ Carbon storage $\left(\mathrm{t} \mathrm{ha}^{-1} \mathrm{C}\right.$ ) in the growth phase } & \multicolumn{2}{|c|}{ Oxygen Produced $\left(\mathrm{t} \mathrm{ha}^{-1} \mathrm{O}_{2}\right.$ ) in the growth phase } \\
\hline & Tree & Sapling & Tree & Sapling \\
\hline Avicennia marina & 4.18 & 1.47 & 11.16 & 3.92 \\
\hline Bruguiera cylindrical & 3.42 & 0.25 & 9.13 & 0.67 \\
\hline Bruguiera gymnorrhiza & 0.55 & 0.20 & 1.47 & 0.53 \\
\hline Bruguiera parviflora & 1.92 & 0.73 & 5.13 & 1.95 \\
\hline Cerbera manghas & 0.61 & 0.08 & 1.63 & 0.21 \\
\hline Hibiscus tilliaceus & 0.98 & 0.29 & 2.62 & 0.77 \\
\hline Lumnitzera littorea & 2.56 & 0.65 & 6.84 & 1.74 \\
\hline Rhizophora mucronata & 0.27 & 0.04 & 0.72 & 0.11 \\
\hline Rhizophora stylosa & 6.47 & 3.09 & 17.27 & 8.25 \\
\hline Sonneratia alba & 4.62 & 0.50 & 12.34 & 1.34 \\
\hline Sonneratia caseolaris & 1.25 & 0.70 & 3.34 & 1.87 \\
\hline Xylocarpus granatum & 6.92 & 1.27 & 18.48 & 3.39 \\
\hline Xylocarpus moluccensis & 2.13 & 0.46 & 5.69 & 1.23 \\
\hline Total & 35.88 & 9.73 & 95.80 & 25.98 \\
\hline
\end{tabular}

Table 9: Carbon storage and oxygen produced by mangrove in the seedling growth phase

\begin{tabular}{lll}
\hline Growth phase & Carbon storage $\left(\mathrm{t} \mathrm{ha}^{-1} \mathrm{C}\right) \quad$ Oxygen production $\left(\mathrm{t} \mathrm{ha}^{-1} \mathrm{O}_{2}\right)$ \\
\hline
\end{tabular}

Seedling $0.04 \quad 0.10$

Based on its growth phase, mangrove in tree growth phases have the highest biomass stock (78.60\%) compared to those in saplings (21.31\%) and seedlings (0.09\%) forms.

Carbon storage and oxygen production: The amount of carbon stored in mangrove vegetation at tree is 35.88 and sapling phase is 9.73 total of which is 45.65 ton ha $^{-1} \mathrm{C}$ and the amount of oxygen produced at the same phases is about $121.88 \mathrm{t} \mathrm{ha}^{-1} \mathrm{O}_{2}$. Complete data on carbon stock in and oxygen produced by each mangrove species is shown in Table 8 and 9.

Table 8 shows that accumulative carbon stored by Rhizophora stylosa in both tree and sapling forms is the highest one $\left(9.56 \mathrm{t} \mathrm{ha}^{-1} \mathrm{C}\right)$, compared to those stored by other species in the same growth phases. Rhizophora stylosa also has the highest ability to produce oxygen ( $25.52 \mathrm{t} \mathrm{ha}^{-1} \mathrm{O}_{2}$ ). Meanwhile, Rhizophora mucronata has the lowest ability in storing carbon (0.31 $\mathrm{t} \mathrm{ha}^{-1} \mathrm{C}$ ) and producing oxygen $\left(0.83 \mathrm{tha}^{-1} \mathrm{O}_{2}\right)$.

\section{DISCUSSION}

The number of mangrove types found in research area are smaller compared to the number of mangrove vegetation types in Indonesia. Kusmana ${ }^{27}$ states that the composition of mangrove vegetation types in Indonesia includes 47 species of trees, 5 species of shrub, nine species of herbaceous plants and grasses and 2 types of parasitic plants. Noor et al. (cited in Pramudji) ${ }^{28}$ shows that Indonesia's forests are home for about 202 mangrove species, consisting of 89 species of trees (wooden vegetation), 5 types of palm, 19 types of climbers, 44 types of Tracheophyta, 44 types of epiphytes and 1 type of fern.

Major mangrove species are the most often observed species compared to minor mangrove and associated species (Table 2). This condition is related to the ability of mangrove groups that quickly adapt to their habitats so that they can form a pure stand community. Tomlinson ${ }^{29}$ suggests that the characteristics of major mangrove species are: (a) Not found in terrestrial/terrestrial communities, (b) Has a major role in the structure of mangrove vegetation communities and is able to form pure stands, (c) Able to adapt to their habitat by the formation of special morphology and (d) Able to grow at low to high salinity levels. While minor mangrove species and mangrove associations generally grow in seashore area that tend toward the mainland and do not form pure stands.

Analysis of mangrove vegetation density shows that the status of the condition of mangrove forests in study site categorized as "good" criteria. These criterions refer to the standard mangrove damage criteria ${ }^{30}$, where the criteria for "good mangrove forests" have a stand density $>1500 \mathrm{~N} \mathrm{ha}^{-1}$ and tree-covered area are larger than $70 \%$ of total land. This condition is also strengthened by the high vegetation density of the seedling growth phase and the phenomenon of decreasing the number of vegetation densities during the sapling and tree growth phases. The phenomenon of decreasing the amount of vegetation density forms an inverted "J" curve, which means that the rate of regeneration of the seedling growth phase in the mangrove forest can guarantee the survival of the stands in the future ${ }^{31}$. 
Rhizophora stylosa is the most dominant type among other types in the seedling, sapling and tree growth phase. The dominance of a species in a vegetation community shows that it has a better level of adaptation to its habitat ${ }^{32}$. Rhizophora stylosais a type of major mangrove group that has a major role and tends to form mangrove communities and can form pure stands and can grow at low to high salinity levels. Also, the species can utilize nutrients or minerals, sunlight energy and water well in its growth process, has a competitive nature and tends to have a good ability to adapt to environmental factors ${ }^{33,34}$. Rhizophora stylosa has a broad range of environmental coverage compared to other species so that it can dominate the existence of other species found at the study site. Odum ${ }^{35}$ stated that the dominance of a type of vegetation can be interpreted to have a broader range of environmental ranges and have an impact on the broad range of tolerance of environmental factors to cause wider distribution of vegetation.

The potential for biomass storage of mangrove vegetation is higher than mangrove forest vegetation in canopy cover in Sebatuana Village, Sambas Regency, West Kalimantan ${ }^{36}$, at $62.08 \mathrm{t} \mathrm{ha}^{-1}$. However, it is lower when compared to the potential storage of Perancak mangrove vegetation in Bali's Jembrana Regency ${ }^{37}$, which is 312,653 t ha $^{-1}$. According to Donato et a $/ .^{38}$, in Southeast Asia, good mangrove ecosystems have biomass potential ranging from 250-275 $\mathrm{t} \mathrm{ha}^{-1}$ and the lowest $<7.9 \mathrm{t} \mathrm{ha}^{-1}$.

The average diameter of the trunk influences the number of biomass potential in the tree growth phase. The average trunk diameter of the tree is $18.77 \mathrm{~cm}$, higher than the average diameter of the sapling phase of $5.31 \mathrm{~cm}$. Stem diameter and height, soil fertility, vegetation density and wood density can affect the potential value of biomass storage in mangrove ecosystems ${ }^{39}$. Seedling growth phase has the lowest biomass storage potential because generally, the seedling growth is still in the form of hypocotyl derived from fruit so that the amount of biomass produced is still limited ${ }^{40}$.

The amount of carbon stored in mangrove vegetation is influenced by the value of biomass stored in vegetation. The higher the value of vegetation biomass, the carbon stored will be even higher. The potential carbon stock of mangrove vegetation results of this study $\left(45.65 \mathrm{t} \mathrm{ha}^{-1} \mathrm{C}\right)$ tends to be lower compared to the carbon stored in mangrove forest stands in the estuary of Gembong Bekasi Regency ${ }^{41}$ at $55.35 \mathrm{t} \mathrm{ha}^{-1} \mathrm{C}$. Primary mangrove forest ecosystems in Indonesia have carbon deposits ranging from 41.80-393.62 tha-1 $\mathrm{C}$ with an average of $188.30 \mathrm{t} \mathrm{ha}^{-1}$ and in secondary mangrove forests around $37.03-142.90 \mathrm{t} \mathrm{ha}^{-1}$ with an average $\mathrm{e}^{42}$ of $94.07 \mathrm{t} \mathrm{ha}^{-1}$, while the potential carbon storage of mangrove forests for Kalimantan bioregion averages $162 \mathrm{t} \mathrm{ha}^{-1} \mathrm{C}$ in primary mangrove forests and $116 \mathrm{t} \mathrm{Cha}^{-1}$ in secondary mangrove forests $\mathrm{s}^{43}$.

Forest vegetation acts as oxygen producer through the process of photosynthesis. The results of this study indicate that oxygen $\left(\mathrm{O}_{2}\right)$ produced by mangrove at tree growth phases $\left(95.80 \mathrm{tha}^{-1} \mathrm{O}_{2}\right)$ is higher than the of $\mathrm{O}_{2}$ produced by the tree stands in urban forests of Palangka Raya City ${ }^{44}$, that is $49.84 \mathrm{tha}^{-1} \mathrm{O}_{2}$. In term of the growth phase, it is known that tree vegetation contributes the most in producing oxygen compared to the sapling and seedling phases, which is caused by the higher ability of trees to absorb $\mathrm{CO}_{2}$ compared to saplings and seedlings. If the absorption of $\mathrm{CO}_{2}$ during photosynthesis exceeds the amount of $\mathrm{CO}_{2}$ released in the respiration process throughout the year, the tree will store carbon higher so that the amount of oxygen produced will be higher. Julius and Nage ${ }^{45}$ states that the more vegetation and forest area, the amount of $\mathrm{CO}_{2}$ absorbed by the leaf surface for photosynthesis will increase so that the amount of $\mathrm{O}_{2}$ produced will be higher. Supriatna ${ }^{46}$ stated that tropical forests are capable of producing much oxygen $\left(600,000 \mathrm{t} \mathrm{ha}^{-1} /\right.$ year $\left.\mathrm{O}_{2}\right)$ compared to lush agricultural areas $\left(20,000-40,000\right.$ t ha $^{-1} /$ year $\left.\mathrm{O}_{2}\right)$.

This study only calculates the potential for biomass stock and vegetation carbon at tree, sapling and seedling growth phases, whereas biomass and carbon stored in understorey vegetation, litter, deadwood and soil have not been studied. Therefore, it is necessary to calculate the biomass and carbon in understorey vegetation, litter, deadwood and soil to obtain more accurate data about carbon stored in mangrove forest.

\section{CONCLUSION}

The number of mangrove vegetation types that are found is relatively small and most are included in the group of major mangrove types. The rate of regeneration of mangrove vegetation for future survival is categorized "quite good" because the density of vegetation is dominated by seedling growth phase. The most dominant type of vegetation is Rhizophora stylosa in the growth phase of trees, saplings and seedlings. It is necessary to conduct mangrove forest conservation in order to increase the potential of biomass storage, carbon stocks and oxygen production.

\section{SIGNIFICANCE STATEMENT}

This study discovered that the mangrove vegetation has the potential to store biomass, to absorb carbon and to produce oxygen that can be beneficial for human and coastal life. This study will help the researchers to uncover the critical areas of oxygen production from the coastal zone that many researchers were very limited to cover. 


\section{REFERENCES}

1. Fawzi, N.I., 2018. Analysis changes and management strategy of mangrove forest in Gunung Palung national park, North Kayong Regency, West Kalimantan. Coastal Ocean J., 1:27-38.

2. Thaler, G.M. and C.A.M. Anandi, 2017. Shifting cultivation, contentious land change and forest governance: The politics of swidden in East Kalimantan. J. Peasant Stud., 44: 1066-1087.

3. Maru, R., R. Umar, S. Nyompa, T. Ismail, A. Arfan, S. Zhiddiq and U. Sideng, 2018. Mapping of poverty characteristics, based on the quality of Fisherman's house, Bajo Tribe, South Halmahera, Indonesia. J. Phys.: Conf. Ser., 1028, No. 1. 10.1088/1742-6596/1028/1/012007.

4. Malik, A., R. Fensholt and O. Mertz, 2015. Economic valuation of mangroves for comparison with commercial aquaculture in South Sulawesi, Indonesia. Forests, 6: 3028-3044.

5. Damastuti, E. and R. de Groot, 2019. Participatory ecosystem service mapping to enhance community-based mangrove rehabilitation and management in Demak, Indonesia. Regional Environ. Change, 19: 65-78.

6. Afkar and N. Aldyza, 2018. The status of conservation of mangroves in the Krueng reuleng river area, Leupung, Aceh Besar Regency, Indonesia. Proc. MICoMS (Emerald Reach Proc. Ser.), 1: 451-455.

7. Peng, M. and K.L. Oleson, 2017. Beach recreationalists' willingness to pay and economic implications of coastal water quality problems in Hawaii. Ecol. Econ., 136: 41-52.

8. Badan Pusat Statistik Kotawaringin Barat, 2014. Kotawaringin barat dalam angka. BPS. https://kobarkab.bps.go.id/ publication.html?page $=8$.

9. Kusmana, C., S. Wilarso, I. Hilwan, P. Pamoengkas and C. Wibowo etal., 2003. Teknik rehabilitasi mangrove. Fakultas Kehutanan Institut Pertanian Bogor, Bogor.

10. Curtis, J.T., 1959. The Vegetation of Wisconsin: An Ordination of Plant Communities. University of Wisconsin Press, Madison, WI., USA., Pages: 657.

11. Kiruba-Sankar, R., P. Krishnan, S.D. Roy, J.R.J. Angel and M.P. Goutham-Bharathi et al., 2018. Structural complexity and tree species composition of mangrove forests of the Andaman Islands, India. J. Coastal Conserv., 22: 217-234.

12. Yuen, J.Q., T. Fung and A.D. Ziegler, 2016. Review of allometric equations for major land covers in SE Asia: Uncertainty and implications for above-and below-ground carbon estimates. For. Ecol. Manage., 360: 323-340.

13. Komiyama, A., S. Poungparn and S. Kato, 2005. Common allometric equations for estimating the tree weight of mangroves. J. Trop. Ecol., 21: 471-477.

14. Dharmawan, I.W.S., 2010. Pendugaan biomasa karbon di atas permukaan tanah pada tegakan Rhizophora mucronata di Ciasem, Purwakarta. J. Ilmu Pertanian Indones., 15: 50-56.
15. Dharmawan, I.W.S. and C.A. Siregar, 2008. Karbon tanah dan pendugaan karbon tegakan Avicennia marina (Forsk.) vierch di ciasem purwakarta. J. Penelitian Hutan Konservasi Alam, 5: 317-328.

16. Clough, B.F. and K. Scott, 1989. Allometric relationships for estimating above-ground biomass in six mangrove species. For. Ecol. Manage., 27: 117-127.

17. Tarlan, M.A., 2008. Biomass estimation of nyirih (Xylocarpus granatum Koenig) in primary mangrove forest in Batu Ampar, West Kalimantan. Undergraduate Thesis, Bogor Agricultural University, Indonesia.

18. Kauffman, J.B. and D. Donato, 2012. Protocols for the measurement, monitoring and reporting of structure, biomass and carbon stocks in mangrove forests. Center for International Forestry Research, Bogor, Indonesia.

19. ITTO., 2013. Penyusunan Baseline Data Pengelolaan Ekosistem Mangrove Di Pulau Bintan. Direktorat Jenderal, Bina Pengelolaan Daerah Aliran Sungai dan Perhutanan Sosial Kementerian Kehutanan.

20. Comley, B.W.T. and K.A. McGuinness, 2005. Above- and below-ground biomass and allometry, of four common northern Australian mangroves. Aust. J. Bot., 53: 431-436.

21. Tamai, S., T. Nakasuga, R. Tabuchi and K. Ogino, 1986. Standing biomass of mangrove forests in Southern Thailand. J. Jap. For. Soc., 68: 384-388.

22. Poungparn, S., A. Komiyama, V. Intana, S. Piriyaota and T. Sangtiean et al., 2002. A quantitative analysis on the root system of a mangrove, Xylocarpus granatum Koenig. Tropics, 12: 35-42.

23. Kauffman, J.B., C. Heider, T.G. Cole, K.A. Dwire and D.C. Donato, 2011. Ecosystem carbon stocks of Micronesian mangrove forests. Wetlands, 31: 343-352.

24. Hairiah, K., A. Ekadinata, R.R. Sari and S. Rahayu, 2011. Pengukuran cadangan karbon: dari tingkat lahan ke bentang lahan. Petunjuk Praktis, Edisi Kedua, Bogor, World Agroforestry Centre, ICRAF SEA Regional Office, University of Brawijaya (UB). Malang, Indonesia.

25. Badan Standarisasi Nasional, 2011. Pengukuran dan penghitungan cadangan karbon-pengukuran lapangan untuk penaksiran cadangan karbon hutan (Ground based fores carbon accounting). http://www.bsn.go.id

26. Nowak, D.J., R. Hoehn and D.E. Crane, 2007. Oxygen production by urban trees in the United States. Arboricult. Urban For., 33: 220-226.

27. Kusmana, C., 2011. Management of mangrove ecosystem in Indonesia. J. Natl. Resourc. Environ. Manage., 1: 152-157.

28. Pramudji, 2001. Ekosistem hutan mangrove dan peranannya sebagai habitat berbagai fauna aquatik. J. Oseana, 26: 13-23.

29. Tomlinson, P.B., 1984. The Botany of Mangroves. Cambridge University Press, Cambridge, UK. 
30. Kementerian Lingkungan Hidup, 2004. Keputusan menteri negara lingkungan hidup No. 201 Tahun 2004 Tentang kriteria baku dan pedoman kerusakan hutan mangrove. Kementerian Lingkungan Hidup, Jakarta.

31. Daniel, T.W., J.A. Helms and F.S. Baker, 1987. Prinsip-Prinsip Silvikultur. 2nd Edn., UGM Press, Indonesia.

32. Junaedi, A. and N. Hidayat, 2015. Struktur dan komposisi vegetasi di areal bekas tebangan berdasarkan zone kelerengan. J. Hutan Trop., 3: 91-98.

33. Heriyanto, N.M. and E. Subiandono, 2012. Komposisi dan struktur tegakan, biomasa, dan potensi kandungan karbon hutan mangrove di taman nasional alas purwo. J. Penelitian Hutan Konservasi Alam, 9: 23-32.

34. Silaen, I.F., B. Hendrarto and M.N. Supardjo, 2013. Distribusi dan kelimpahan gastropoda pada hutan mangrove Teluk Awur Jepara. Manag. Aquatic Resourc. J., 2: 93-103.

35. Odum, E.P., 1993. Dasar-Dasar Ekologi. (Penerjemah Tjahyono Samingan dan Penyunting B. Srigindo). Gadjah Mada University Press, Yogyakarta.

36. Mulyadi, D. Astiani and T.F. Manurung, 2017. Potensi karbon pada tegakan hutan mangrove di desa sebatuan kabupaten sambas. J. Hutan Lestari, 5: 592-598.

37. Suryono, S., N. Soenardjo, E. Wibowo, R. Ario and E.F. Rozy, 2018. Estimasi kandungan biomassa dan karbon di hutan mangrove perancak Kabupaten Jembrana, Provinsi Bali. Buletin Oseanografi Marina, 7: 1-8.

38. Donato, D.C., J.B. Kauffmann, D. Murdiyarso, S. Kurnianto, M. Stidham and M. Kanninen, 2011. Mangroves among the most carbon-rich forests in the tropics. Nat. Geosci., 4: 293-297.
39. Kusmana, C. and S. Sabiham, 1992. An estimation of above ground tree biomass of a mangrove forest in East Sumatra, Indonesia. Tropics, 1: 243-257.

40. Hilmi, E., 2003. Model Penduga kandungan karbon pada pohon kelompok jenis Rhizophora spp. dan Bruguiera spp. dalam Tegakan Hutan Mangrove (Studi Kasus di Indragiri Hilir Riau). Disertasi, Program Pascasarjana, Institut Pertanian Bogor.

41. Rachmawati, D., I. Setyobudiandi and E. Hilmi, 2014. Potensi estimasi karbon tersimpan pada vegetasi mangrove di wilayah pesisir muara gembong Kabupaten Bekasi. Omni-Akuatika, 10: 85-91.

42. Rochmayanto, Y., A. Wibowo, M. Lugina, T. Butarbutar, R.M. Mulyadin, D. Wicaksono and T. Rusulono, 2014 Cadangan Karbon pada Berbagai Tipe Hutan dan Jenis Tanaman di Indonesia (Seri 2). PT Kanisius, Yogyakarta, Indonesia.

43. Krisnawati, H., W.C. Adinughroho, R. Imanuddin and S. Hutabarat, 2014. Pendugaan Biomassa Hutan untuk Perhitungan Emisi $\mathrm{CO}_{2}$ di Kalimantan Tengah. Pusat Penelitian dan Pengembangan Konservasi dan Rehabilitasi, Badan Penelitian dan Pengembangan Kehutanan, Bogor, Indonesia, ISBN: 978-602-1681-09-1.

44. Ludang, Y., A. Junaedi and E.P.Putir, 2016. Potensy estimation on oxygen production of tree stage vegetation at the Himba Kahui Urban Forest Palangka Raya. Acta Scientiae Intelectus, 2: 94-100.

45. Julius, P. and F. Nagel, 2011. Pelestarian Hutan dalam Hubungannya dengan Lingkungan dan Potensi Ekonomi. Universitas Gunadarma, Depok. http://repository.gunadarma. ac.id/1466/

46. Supriatna, J., 2008. Melestarikan Alam Indonesia. Yayasan Obor Indonesia, Jakarta. 